\title{
Erratum to: Preliminary Studies for Cephamycin C Purification Technique
}

\author{
Álvaro de Baptista Neto • Maritza Catalina Condori Bustamante • \\ Jaine Honorata Hortolan Luiz de Oliveira • Ana Cláudia Granato • \\ Carolina Bellão • Alberto Colli Badino • Marlei Barboza • Carlos Osamu Hokka
}

Published online: 7 December 2011

(C) Springer Science+Business Media, LLC 2011

\section{Erratum to: Appl Biochem Biotechnol DOI 10.1007/s12010-011-9417-6}

The original version of this article unfortunately contained a mistake. The name of the sixth author is incorrect. The correct name is "Alberto Colli Badino". In the article footnote, "A.C. B. Junior" should read as "A.C. Badino".

The online version of the original article can be found at http://dx.doi.org/10.1007/s12010-011-9417-6.

M. C. C. Bustamante • C. Bellão • A. C. Badino • C. O. Hokka

Department of Chemical Engineering, Universidade Federal de São Carlos, Cx. Postal 676, CEP 13565-905 São Carlos, SP, Brazil

A. C. Granato $\cdot$ M. Barboza $(\bowtie)$

Department of Chemical Engineering, Universidade Federal do Triângulo Mineiro, Cx. Postal 676, CEP 13565-905 São Carlos, SP, Brazil

e-mail: marlei@ufscar.br

J. H. H. L. de Oliveira

Department of Pharmacy, Universidade Federal de Alfenas, Cx. Postal 676, CEP13565-905 São Carlos, SP, Brazil

Á. de Baptista Neto

Verdartis Desenvolvimento Biotecnológico Ltda-ME, Rua dos Técnicos s/n sala 5,

Incubadora Supera Campus USP, CEP 14040-900 Riberão Preto, SP, Brazil 